\title{
Comment on the New DGGG AWMF S3-Guideline on Hysterectomy, or a Plea for LAVH as the Gold Standard for Total Hysterectomy Procedures
}

\author{
Kommentar zu der neuen DGGG-AWMF-S3-Leitlinie „Hysterektomie“ oder \\ ein Plädoyer für die LAVH als Goldstandard bei der totalen Hysterektomie
}

Author

Affiliation

\section{R. L. De Wilde}

Director of the Klinik für Frauenheilkunde, Geburtshilfe und Gynäkologische Onkologie, Universitätsklinik für Gynäkologie, Pius-Hospital Oldenburg, Carl von Ossietzky Universität Oldenburg, Oldenburg
Deutsche Version unter: www.thieme-connect.de/ ejournals/gebfra
Bibliography

DOI http://dx.doi.org/

10.1055/s-0035-1568167

Geburtsh Frauenheilk 2016; 76 :

365-366 @ Georg Thieme

Verlag KG Stuttgart · New York .

ISSN 0016-5751

\section{Correspondence}

Rudy Leon De Wilde,

Director of the Klinik für

Frauenheilkunde, Geburtshilfe und Gynäkologische Onkologie Universitätsklinik

für Gynäkologie

Pius-Hospital Oldenburg

Carl von Ossietzky Universität

Oldenburg

Georgstraße 12

26121 Oldenburg

rudy-leon.dewilde@

pius-hospital.de
I would like to start by congratulating Professors Klaus Neis (Saarbrücken) and Matthias Beckmann (Erlangen) for their work in coordinating the contributions to the Hysterectomy guideline. The AWMF S3-guideline was formulated in consensus with the German, Austrian and Swiss Societies for Gynecology and Obstetrics (DGGG, ÖGGG, SGGG). The guideline discusses the indications and methods used for hysterectomy based on an extensive search of the literature (1990-2012). The search included reviewing more than 450 citations, of which just under 300 were taken into account [1]. The international consensus reached with regard to total hysterectomy procedures was that abdominal hysterectomies should be avoided where possible, with preference being given to vaginal hysterectomies. If a vaginal hysterectomy does not appear feasible, the proposed alternative is total laparoscopic hysterectomy.

Opinions may differ with regard to the merits and demerits of the increasing numbers of certifications and guidelines issued in recent years, but at least they serve as signposts and practical guides for physicians and other medical professionals looking for information on the topic and also provide orientation to patients.

After laparoscopically assisted vaginal hysterectomy (LAVH) was first described in Germany at the beginning of the 1980s [2], the concept was later accepted and implemented internationally [3]. As a surgical procedure for total hysterectomy, LAVH combines the known benefits of vaginal hysterectomy with those of laparoscopic hysterectomy; however it avoids the documented drawbacks of abdominal and laparoscopic hysterectomy procedures [4]. The complications associated with laparoscopic hysterectomy such as bladder or ureteral lesions and the complications associated with total abdominal hysterectomy procedures such as intestinal obstructions and the stress of laparotomy are significantly lower with LAVH procedures [5]. Given the proper training and preparation, the repositioning required when access is switched from a laparoscopic to a vaginal approach is nothing more than a simple technical operation. LAVH also allows other surgical procedures to be carried out concomitantly, for example the laparoscopic removal of adhesions [6,7], adnexal tumors, endometriosis, ... [8] Preparations for the vaginal part of the hysterectomy can partly be done during laparoscopy, which will allow vaginal removal of the uterus to be done at a significantly lower risk, possibly even following morcellation with a knife $[9,10]$. Very often, subsequent vaginal hysterectomy procedures can be carried out without morcellation or after morcellation using only a knife, at all events without abdominal electric morcellation. Intraabdominal electronic morcellation has recently been extensively debated, and it is not necessary to use this procedure as in LASH or total laparoscopic hysterectomy [11,12]. Electric power morcellation needs to be evaluated in epidemiological or prospective studies before it is possible to give a final opinion on the associated risk of sarcoma dissemination [13,14]. Several additional techniques have been described which can be used to remove even very large uteri in patients with a very narrow vagina or which are $s / p$ cesarean section or nullipara per vaginam [15]. Using LAVH for total hysterectomy combines the benefits of minimal access surgery; it offers the maximum degree of invasiveness required and access through the natural orifices (Natural Orifice Trans-Luminal Endoscopic Surgery, NOTES) [16] but without additionally requiring expensive robotic assistance [17].

The school which favors a vaginal approach is well served by the large population of gynecological surgeons in Germany, as not all have the ability and knowledge to perform laparoscopic surgery at the very highest level. In terms of health policies the approach can be comprehensively offered to patients across the country. From a profession- 
al point of view, the expertise required to perform vaginal hysterectomy - and after all, LAVH is only a variant of this form of surgery - is only available from gynecological surgeons, which additionally protects our field from other medical specialties.

In summary, based on the newly compiled guideline on hysterectomy which, in turn, was based on a review of the existing national and international literature, because of its safety and efficacy as well as the reduced numbers of complications LAVH must be considered the gold standard for total hysterectomy.

\section{Conflict of Interest}

There is no conflict of interest.

\section{References}

1 Neis K, Kreienberg R, Beckmann MW et al. S3-Leitlinie zur Indikation und Methodik der Hysterektomie. AWMF online. Online: www.awmf. org/uploads/tx_szleitlinien/015-070e_S3_Indikation_und_Methodik_ der_Hysterektomie_2015-07.pdf; last access: 21.12.2015

2 Raatz D. Preoperative laparoscopy for determination of the surgical approach. Geburtsh Frauenheilk 1985; 45: 898-900

3 Reich H. Laparoscopic hysterectomy. Surg Laparosc Endosc 1992; 2: $85-88$

4 Müller A, Thiel FC, Renner SP et al. Hysterectomy - a comparison of approaches. Dtsch Arztebl Int 2010; 107: 353-359

5 Cipullo L, Cassese S, Fasolino L et al. Laparoscopic hysterectomy and urological lesions: risk analysis based on current literature and preventive strategies. Minerva Ginecol 2008; 60: 331-337
6 De Wilde RL, Trew G. Postoperative abdominal adhesions and their prevention in gynaecological surgery. Gynecol Surg 2007; 4: 161-168

7 De Wilde RL, Trew G. Postoperative abdominal adhesions and their prevention in gynaecological surgery. Part 2. Gynecol Surg 2007; 4: 243253

8 Yi YX, Zhang W, Zhou Q et al. Laparoscopic-assisted vaginal hysterectomy vs. abdominal hysterectomy for benign disease: a meta-analysis of randomized controlled trials. Eur J Obstet Gynecol Reprod Biol 2011; 159: $1-18$

9 Schmidt EH, De Wilde RL. Standardverfahren der minimal-invasiven Chirurgie in der Frauenheilkunde. Stuttgart: Thieme; 1998: 137-145

10 Brandner P, Neis KJ. The significance of laparoscopically-assisted vaginal hysterectomy - LAVH. Zentralbl Gynakol 1995; 117: 620-624

11 Bojahr B, De Wilde RL, Tchartchian G. Malignancy rate of 10,731 uteri morcellated during laparoscopic supracervical hysterectomy (LASH). Arch Gynecol Obstet 2015; DOI: 10.1007/s00404-015-3696-z

12 Tanos V, Brölmann H, De Wilde RL et al. Myoma morcellation and sarcoma panic. Gyn Surg 2015; 12: 17-19

13 Brölmann H, Tanos V, Grimbizis G et al. Options on fibroid morcellation. Gyn Surg 2015; 12: 3-15

14 Nezhat C. Morcellation during uterine tissue extraction. Online: www. aagl.org/wpcontent/uploads/2014/05/Tissue_Extraction_TFR.pdf; last access: 21.12.2015

15 Tchartchian G, Dietzel J, Bojahr B et al. No more abdominal hysterectomy for myomata using a new minimally-invasive technique. Int J Surg Case Rep 2010; 1: 7-8

16 Mohan HM, O'Riordan JM, Winter DC. Natural-orifice translumenal endoscopic surgery (NOTES): minimally invasive evolution or revolution? Surg Laparosc Endosc Percutan Tech 2013; 23: 244-250

17 De Wilde RL, Herrmann A. Robotic surgery - advance or gimmick? Best Pract Res Clin Obstet Gynaecol 2013; 27: 457-469 